\title{
Review
}

\section{Downsizing of Lean Body Mass is a Key Determinant of Alzheimer's Disease}

\author{
Yves Ingenbleek ${ }^{\mathrm{a}, *}$ and Larry H. Bernstein ${ }^{\mathrm{b}}$ \\ ${ }^{a}$ Laboratory of Nutrition, Faculty of Pharmacy, University Louis Pasteur, Strasbourg, France \\ ${ }^{\mathrm{b}}$ Laboratory of Clinical Pathology, New York Methodist Hospital, Weill-Cornell University, New York, NY, USA
}

Accepted 3 October 2014

\begin{abstract}
Lean body mass (LBM) encompasses all metabolically active organs distributed into visceral and structural tissue compartments and collecting the bulk of $\mathrm{N}$ and $\mathrm{K}$ stores of the human body. Transthyretin (TTR) is a plasma protein mainly secreted by the liver within a trimolecular TTR-RBP-retinol complex revealing from birth to old age strikingly similar evolutionary patterns with LBM in health and disease. TTR is also synthesized by the choroid plexus along distinct regulatory pathways. Chronic dietary methionine (Met) deprivation or cytokine-induced inflammatory disorders generates LBM downsizing following differentiated physiopathological processes. Met-restricted regimens downregulate the transsulfuration cascade causing upstream elevation of homocysteine (Hcy) safeguarding Met homeostasis and downstream drop of hydrogen sulfide $\left(\mathrm{H}_{2} \mathrm{~S}\right)$ impairing anti-oxidative capacities. Elderly persons constitute a vulnerable population group exposed to increasing Hcy burden and declining $\mathrm{H}_{2} \mathrm{~S}$ protection, notably in plant-eating communities or in the course of inflammatory illnesses. Appropriate correction of defective protein status and eradication of inflammatory processes may restore an appropriate LBM size allowing the hepatic production of the retinol circulating complex to resume, in contrast with the refractory choroidal TTR secretory process. As a result of improved health status, augmented concentrations of plasma-derived TTR and retinol may reach the cerebrospinal fluid and dismantle senile amyloid plaques, contributing to the prevention or the delay of the onset of neurodegenerative events in elderly subjects at risk of Alzheimer's disease.
\end{abstract}

Keywords: Alzheimer's disease, homocysteine, hydrogen sulfide, lean body mass, nutritional assessment, retinoids, transthyretin

\section{INTRODUCTION}

Plasma transthyretin (TTR) was initially proposed as an index of protein-depleted states following field surveys undertaken in Senegal (West Africa) on children suffering from varying stages of malnutrition ranging from cachectic marasmus to edematous kwashiorkor [1]. The serum analyte is now widely measured in developing areas for the nutritional follow-up of underprivileged populations [2,3] and in developed countries to screen hospitalized patients who require dietary management $[4,5]$. Several

*Correspondence to: Yves Ingenbleek, MD PhD, 15 bis, rue de la Vise, F-34540 Balaruc le Vieux, France. Tel.: +33 4677487 17; E-mail: ingen@unistra.fr. neurological investigations have recently reported the innovative observation that the same TTR biomarker impacts on the outcome of Alzheimer's disease (AD) $[6,7]$, raising the basic premise that alterations of protein status might be implicated in neurodegenerative disorders. Preliminary studies have indeed suggested that the reliability of the TTR indicator is based on its accurately identifying loss of lean body mass (LBM) [8] effecting metabolically active tissues in health and disease. The below review describes the unrecognized correlations linking LBM entity to TTR fluctuations and the mechanisms whereby LBM downsizing, as determined by declining TTR plasma concentrations, generates significant public health consequences in neurodeteriorating morbidities, taking $\mathrm{AD}$ as exemplary. 


\section{MAIN LEAN BODY MASS CHARACTERISTICS}

The simplest methodology aiming at assessing body composition and LBM measurement refers to a binary system taking the difference between fat mass and body weight. Dual-energy X-ray absorptiometry measures $\gamma$-rays emitted by the naturally occurring radioisotope ${ }^{40} \mathrm{~K}, 95 \%$ of $\mathrm{K}$ being intracellular in metabolically active tissues [9]. Dual-energy X-ray absorptiometry, regarded as a gold standard, accurately measures LBM assuming that total body potassium (TBK) values are tightly correlated with total body nitrogen within an average $\mathrm{K} / \mathrm{N}$ ratio of about $3 \mathrm{mEq} \mathrm{K} / \mathrm{g} \mathrm{N}$ [10]. In healthy adult males, LBM contains the bulk of total body nitrogen $(1,800 \mathrm{~g}$ or $64 \mathrm{~mol})$ and of TBK $(140 \mathrm{~g}$ or 3,600 mmol) (Fig. 1) [11]. LBM may be schematically subdivided into the visceral protein compartment, characterized by rapid turnover rates, consisting of the liver, small intestinal mucosa and hemopoietic tissue, and the structural protein compartment, distinguished by slower turnover rates, comprising the muscle mass, skin and connective tissues [12]. Pioneering studies performed by Brožek and Grande on human adults have shown that hepatic tissues manifest an oxygen consumption rate $\left(44 \mathrm{ml} \mathrm{O}_{2} / \mathrm{Kg}\right.$ ) about 20-fold higher than the muscle mass $\left(2.3 \mathrm{ml} \mathrm{O}_{2} / \mathrm{Kg}\right)$ [13]. Moreover, the fractional synthesis rate of total liver proteins (stationary and exported) equals approximately $25 \%$ of the daily hepatic protein content [14] contrasting with the muscle mass turnover at $1.7 \%$ /day [15]. The fractional synthesis rate of the gut mucosa protein is close to $10 \% /$ day [16], whereas that of lymphocytes reaches $7 \%$ of the whole body protein turnover [17]. The data imply that, on a ponderal basis, the protein turnover in visceral organs is about 10 to 20-times faster than that of the skeletal muscle mass. However, comparing the liver mass $(2.6 \%$ of body weight [9] at $1.7 \mathrm{Kg}$ ) with that of the musculature (37\% of body weight [18] or $26 \mathrm{Kg}$ ), both components contribute equally to the basal metabolic activities daily estimated at $26.4 \%$ and $25.6 \%$, respectively [13]. These studies conducted nearly 60 years ago are confirmed by a more recent clinical investigation showing that liver and musculature, principal determinants of resting energy expenditure, together generate $50 \%$ of the basal metabolic expenditure [19].

A good example of the dichotomous LBM partitioning into visceral and structural activities is provided by patients undergoing chronic renal failure. The concomitant measurement of LBM using $\mathrm{TBK}^{40}$ method and creatinine generation rate in kidney patients resulted in a systematic underestimation of the latter technique when compared to the former [20]. This discrepancy lies in the creatinine generation rate method only identifying the structural component of LBM but failing to measure the metabolically active visceral component. This comparative peritoneal dialysis study led to the conclusion that creatinine generation rate is an inappropriate parameter to appraise LBM

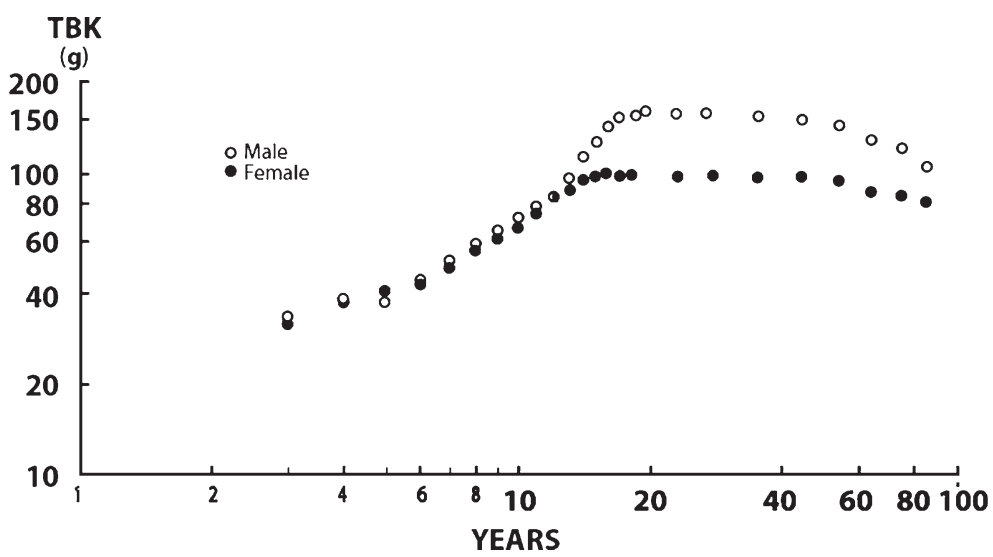

Fig. 1. Body accretion of TBK values during the life span of healthy subjects. Normal TBK values determined by the measurement of ${ }^{40} \mathrm{~K}$ using dual-energy X-ray absorptiometry and resulting from the compilation of seven different clinical investigations performed on healthy subjects [9]. LBM evolutionary patterns disclose striking age- and gender-similarities with TTR trajectory: linearly rising and superimposable LBM values from birth until the onset of puberty, occurrence of sexual dimorphism between adolescent males and females, then stabilization of TBK values (male/female ratio turning around 1.4) until the age of 65 years followed by gradual downsizing in both sexes with more pronounced decline in elderly males in relation with more marked involutional trends toward sarcopenia $[9,18]$. The figure shows that the normal TBK concentrations turns around 140-160 gr in adult men and around 90-110 gr in adult women [9]. Beyond the age of 65 years, the decennial loss of TBK is estimated at about $5 \%$ in men and $3.5 \%$ in women [9]. 
status in renal patients [20]. Most kidney studies indicate that plasma TTR concentrations have better predictive reliability in assessing outcome [21]. The concept of compartmental specificity is also documented in long-lasting wasting disorders characterized by greater magnitude of TBK over total body nitrogen losses, pointing to a more rapid reduction in skeletal musculature and a relative resistance of visceral tissues [22].

\section{MAIN TTR CHARACTERISTICS}

TTR is a highly conserved protein in vertebrate species secreted by the choroid plexus (CP) of reptiles that has remained confined within the cerebrospinal fluid (CSF) for 300 million years [23]. Liver synthesis of TTR occurred much later, about 100 million years ago, in birds and eutherian mammals [24]. The sole intracerebral site of TTR synthesis is confined to the epithelial cells lining the ventricular surface of the CP $[25,26]$. TTR was identified in human CSF in 1942 [27] whereas the liver-secreted TTR was discovered in human serum in 1956 [28]. TTR is a tryptophan-rich molecule [28] displaying tetrameric conformation, each subunit having a sequence of 127 amino acids (AAs) aggregated within a nonglycosylated edifice of $55 \mathrm{kDa}$ as molecular mass (MM) [29]. TTR is the third specific binding protein that transports thyroid hormones [30] besides serum- albumin and thyroxine-binding globulin. One of the four monomers constituting the tetrameric TTR edifice carries a small companion protein displaying a single binding site for a molecule of all-trans-retinol [31] (retinol-binding protein, RBP, $21 \mathrm{kDa}$ as $\mathrm{MM}$ ) thus forming together a trimolecular retinol circulating complex (RCC) totaling $76 \mathrm{kDa}$ as MM [31, 32]. The International Nomenclature Committee has recommended the denomination of trans-thyr-retin to emphasize the dual conveying roles played by TTR in human serum [33]. Despite different biological halflives (2 days for TTR [34] versus half a day for RBP [35]), the three RCC components are bound at 1:1:1 stoichiometry. Apo-RBP molecules devoid of retinol ligand disclose a significantly reduced $T_{1 / 2}$ and undergo rapid glomerular leakage, tubular disintegration and subsequent recycling of the released AA residues [35]. The data indicate that TTR protects RBP from premature urinary output and serves as a limiting factor for the delivery of retinoid compounds to target tissues [36]. Animal experiments have shown that the liver is the main site for TTR degradation, followed by muscle mass, skin, and kidneys [37].

Newborn plasma TTR concentrations reach roughly two thirds those of their mothers, increasing linearly without sexual difference during infant growth [38]. When puberty begins, major hormonal and metabolic alterations lead to increased height velocity, weight gain, and redistribution of body tissues [39], especially

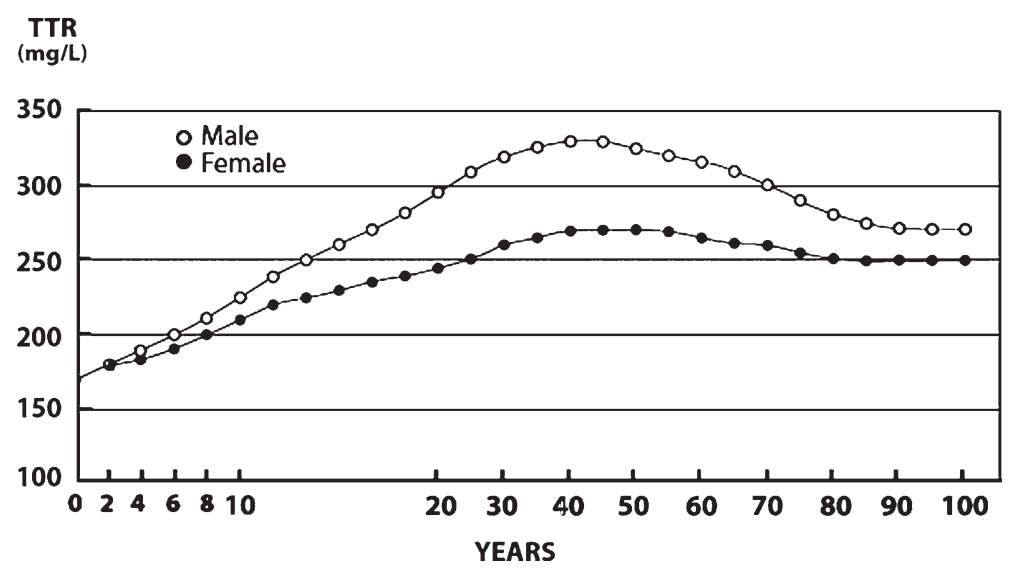

Fig. 2. Evolutionary patterns of normal human TTR values measured in both sexes and extending from birth to the age of 100 years [41]. TTR concentrations were measured on blood samples withdrawn from 68,720 healthy US citizens using the Hitachi $912^{\text {TM }}$ immunoturbidimetric analyzer (Roche Diagnostics, Indianapolis, IN, USA) and monospecific goat antihuman TTR (DiaSorin Inc. Stillwater, MN, USA) [41]. The TTR values, their means, and standard deviations stratified by age and sex are provided with details elsewhere [8]. The results show that TTR values are low at birth, manifest linear increase without sexual difference until the onset of puberty, followed by elevation of TTR values recorded in male teenagers and maintenance in the form of plateau levels during the full sexual maturity period. Starting from the sixties, TTR values reveal stepwise drop in process of time with a steeper slope affecting elderly men that reflects a relatively more rapid deterioration of their muscle mass. This lowering trend is attributed to the attenuation of trophic stimuli and androgenic impregnation in elderly persons [8]. 
muscle mass constituting the main LBM component by weight [18]. The result is an S-shaped growth of LBM greater in male adolescents than the blunted curve documented in teen-aged girls [9]. The gender dimorphism, an evolutionary pattern observed during adolescence for TTR values [40, 41], matches the growth of LBM [9]. During the full sexual maturity period, healthy adults reveal sex-related difference in plasma TTR concentrations stabilized at plateau levels of $300-330 \mathrm{mg} / \mathrm{L}$ in males and around $250-270 \mathrm{mg} / \mathrm{L}$ in females [40, 41] (Fig. 2), whereas RBP plasma values are likewise around $63 \mathrm{mg} / \mathrm{L}$ and $52 \mathrm{mg} / \mathrm{L}$ [40], respectively. The muscle mass begins downsizing in the sixties, with a steeper slope in elderly men $[9,18]$ accounting for the concomitant decline in LBM [9] and TTR-RBP values [40]. The serial measurement of plasma TTR concentrations allows grading the level of protein wasting, $180 \mathrm{mg} / \mathrm{L}$ constituting a boundary predicting serious complications [42] and the threshold of $100 \mathrm{mg} / \mathrm{L}$, presumably reflecting the exhaustion of LBM resources, bearing ominous prognostic significance [43]. Early detection and aggressive nutritional support provided to high risk patients significantly improves their prognostic outcome while alleviating the financial burden of hospitalization [44].

\section{LEAN BODY MASS: TTR INTERRELATIONSHIPS}

The above observations demonstrate for the first time the striking similarities linking LBM and TTR evolutionary patterns throughout the lifetime of human subjects, stressing the functional uniqueness of the plasma biomarker. Due to its short biological half-life, TTR appears as a sensitive responder to any alteration of protein status $[45,46]$ allowing rapid identification of LBM stores. LBM downsizing may be the consequence of either chronic dietary restriction leading to unachieved protein replenishment [47] or to inflammatory disorders causing excessive urinary N-losses [48]. The former condition is described in animal models $[49,50]$ and human subjects $[51,52]$ experiencing methionine (Met)-deprived regimens. The latter condition is reported in liver experiments [53] and clinical studies $[54,55]$ characterized by cytokine-induced inflammatory events. These events are associated with up and down TTR fluctuations, showing that LBM may undergo $\mathrm{N}$ recovery or depletion processes influencing the liver secretory rate of plasma TTR that emerges as the ultimate signal of LBM reserves. We postulate the existence of many intersected linkages and centrally-mediated regulatory mechanisms governing the balance between protein accretion and protein breakdown as well as between inter-organ energy and AA fluxes feeding LBM components.

The data indicate that any nutritional or inflammatory causal factor generates comparable LBM downsizing and shrinking of Met body pools, operating nevertheless throughout unrelated physiological mechanisms. To make short a long story described with details [47], reduced Met bioavailability causes the greatest catabolic losses, depressing protein syntheses nearly as deeply as when protein-free regimens are provided [56]. Maintenance of Met homeostasis is therefore of survival importance as appropriate dietary provision of Met plays crucial roles in the preservation of $\mathrm{N}$ body stores. Met-depleted animals set in motion adaptive mechanisms aiming at adjusting to reduced activity of cystathionine- $\beta$-synthase (CBS, EC 4.2.1.22) enzyme [57, 58] along the transsulfuration (TS) cascade. The blockade promotes upstream accumulation of homocysteine (Hcy) values in body fluids [49-51], serving as a precursor pool readily driven into efficient Hcy $\longrightarrow$ Met remethylation (RM) pathways. The final result affords unmodified Met baseline levels whereas Hcy did manifest gradually rising values as protein status worsens [51] explaining why Hcy and TTR plasma values are inversely correlated and manifest mirror image of each other [8]. Taken together, the data show that, in the case of inadequate Met dietary intake, upsurge of Hcy values operate as the dark side of beneficially stimulated RM processes allowing a safeguard of Met homeostasis. Inhibition of CBS activity generates another important biological effect, namely the downstream synthesis of cysteine (Cys) and glutathione (GSH) reductant molecules [52, 59], accounting for the depressed enzymatic and nonenzymatic physiological production of hydrogen sulfide $\left(\mathrm{H}_{2} \mathrm{~S}\right)$ in body tissues [47].

Met is the main provider of S by the way of dietary items and the content of this indispensable AA (IAA) holds, on a ponderable basis, significant advantage in animal over vegetable kingdoms. $\mathrm{S}$ and $\mathrm{N}$ are indeed closely correlated within stable molar ratios turning around 1:14.5 in mammalian tissues [60] whereas plant products are characterized by lesser $\mathrm{N}$ and $\mathrm{S}$ contents revealing molar ratios usually ranging from 1:20 to 1:35 [60] which do not optimally fulfill human tissue requirements. The data explain why strict vegan subjects incur the risk of permanent $\mathrm{N}$ and $\mathrm{S}$ deficiencies leading to LBM shrinking [47] and upgraded Hcy production [61, 62]. Plant products based upon cereals cannot meet human IAA needs unless at least $30 \%$ of total protein is provided by animal sources [63]. 


\section{THE TTR: LEAN BODY MASS COUPLE IN ALZHEIMER'S DISEASE}

$\mathrm{AD}$ is a common and devastating form of dementia affecting a growing proportion of individuals over the age of 65 years and characterized by the harmful accumulation in the brain of two types of histopathological deposits (1) neurofibrillary tangles formed by aggregates of hyperphosphorylated tau proteins and (2) senile amyloid plaques resulting from selfaggregation of amyloid- $\beta(A \beta)$ peptides with $A \beta_{1-40}$ monomers predominating over the most aggressive $\mathrm{A} \beta_{1-42}$ species [64]. Both inflammatory events and generation of reactive oxidative species (ROS) participate in the breakdown of basal lamina, increasing permeability of the vascular blood-brain barrier (BBB) [65]. The AD plaque is a localized form of amyloid fibril deposit remaining confined to cerebral tissues that has not been identified in other organs of the body [66]. Clear distinction must be made between the cleavage of amyloid- $\beta$ protein precursor into $A \beta$ peptides found in $\mathrm{AD}$ brain and the autosomal dominant amyloidogenic process resulting from the substitution of single or double AA residues at different positions of the normal monomeric TTR sequence. This last mutation process has been first recognized by Andrade [67] in 1952 under the clinical denomination of familial amyloidotic polyneuropathy (FAP) characterized by anomalous protein misfolding and aggregation. At least 100 different mutated variants have been enumerated up to now [68] liable to generate structural and functional damages in most body tissues [66]. Some studies have shown that FAP patients may undergo several stages of protein malnutrition characterized by subnormal TTR plasma values [69]. This clinical anomaly must be regarded as the secondary consequence of FAP-induced liver dysfunction in contrast to the primary role played by protein deficiency in the occurrence of AD disorders. The different conformation and properties distinguishing FAP from AD amyloid products is documented by tissue studies failing to report immunochemical similarities or antigenic cross-reactivity [70, 71].

Several recent investigations performed on matrix metalloproteinases (MMP) enzymes in neurodegenerative processes shed new light in that research domain. $\mathrm{MMP}_{-2}$ and $\mathrm{MMP}_{-9}$ are the two main $\mathrm{Zn}$-dependent endoproteases manifesting ambivalent properties under the regulatory control of a family of four tissue inhibitors of MMPs (TIMPs) [72, 73]. Under physiological circumstances, the highly integrated MMP-TIMP balance maintain normal cell signaling processes, growth promoting activities, release of extracellular matrix, wound healing and angiogenesis of neural tissue [72, 73]. In neuroinflammatory disorders, the MMP-TIMP balance is disrupted, promoting the formation of neurofibrillary tangles and senile amyloid plaques [74] with the participation of mitochondrial cytochrome $\mathrm{C}$ oxidase [75] and caspase-3 [76]. Both MMP-2 and MMP-9 enzymes may conversely exert beneficial effects such as degradation of $A \beta_{1-40}$ [74] and $A \beta_{1-42}$ [77] peptides.

The strong anti-oxidative properties normally elicited by $\mathrm{H}_{2} \mathrm{~S}$ against the deleterious effects of Hcy burden [47] are shown to be impaired in $\mathrm{AD}$ patients owing to their severely depressed intracerebral CBS activity releasing reduced amounts of the gasotransmitter from Cys [78]. Therapeutic proof of the defect is provided by exogenous administration of $\mathrm{H}_{2} \mathrm{~S}$ that protects neurons from ROS stress [79], allows to redress MMP-TIMP imbalance [80] and to mitigate Hcy-induced cerebrovascular dysfunction, memory deficits and inflammatory remodeling [81]. Most $\mathrm{H}_{2} \mathrm{~S}$ molecules decompose into sulfide anions $\left(\mathrm{S}^{2-}\right)$ [82] shown to inhibit the activity of several enzymes implicated in the development of Hcyinduced ROS damages [47]. For example, MMP-2 and $\mathrm{MMP}_{-9}$ in human breast cancer cells are downregulated in a dose-dependent manner by the addition of highly purified $\mathrm{S}$ in the culture media [83]. Likewise, human malignant keratinocytes incubated with elemental $\mathrm{S}$ causes the reduction of cytochrome $\mathrm{C}$ oxidase and caspase- 3 activities in a dose- and time-related manner with subsequent growth inhibition and apoptosis of cancer cells [84]. We assume that elemental S plays the role of cofactor of several enzyme activities critically involved in the regulation of Hcy-dependent oxidative stress [47].

A growing body of neurobiological studies indicates that plasma TTR, RBP, and retinol are effector molecules flowing across the blood-brain barrier and diffusing in CSF to blend together with TTR molecules intrathecally produced. Intracerebral TTR participates in memory [85], cognitive [86], behavioral [87], regenerative [88], and neuroprotective [89] processes. The brain CP manifests declining intrathecal TTR secretory potential with increasing age [90], a regressive process likely to be genetically programmed and poorly responsive to therapeutic manipulation, at variance with plasma-derived TTR and retinoids. The data support the concept that the production of TTR in the liver and in the CP is regulated independently [91], suggesting that the brain might escape most harmful events affecting overall body economy in the course of 
protein-depleted and/or inflammatory states. The first evidence that TTR is capable of preventing $A \beta$ amyloid formation and toxicity was described in experimental studies [92]. TTR works as limiting factor for the plasma transport of retinol [36] which in turn operates as a rate-limiting determinant of both physiologically active cis and trans retinoic acid (RA) derivatives [93]. Under normal ageing process, the concentration of RA compounds [94] and expression of RA receptors [95] are downregulated in cerebral tissues. In adult rat brains, depletion of RAs causes deposition of A $\beta$ peptides, favoring the formation of senile amyloid plaques [96]. Conversely, exogenous administration of RAs restores the expression of retinoid receptors and the control of amyloidogenic pathways [97]. In addition, retinol may disaggregate preformed $A \beta$ fibrils more efficiently than do RAs [98], indicating that the three retinoid molecules operate synergistically to prevent the deterioration of cerebral tissues. Finally, retinol may exert fundamental regulation of mitochondrial energy homeostasis [99] thus contributing to forestall aging processes and cell death [75]. Patients affected by cerebral dysfunction usually have low plasma and intrathecal TTR and RBP concentrations, pointing to underlying malnutrition correlated with disease severity [100-103]. A variety of retinoid compounds are currently recommended in AD patients [104] and under testing with a view to identify potential therapeutic applications [105]. We contend that restoration of an optimal LBM status, as assessed by normal agematched TTR and retinol values, should operate as the best physiological way to prevent or to delay the onset of neurodegenerative events. Other cerebral dysfunctions such as depression [106], schizophrenia [107], and Guillain-Barré syndrome [108] are reportedly characterized by comparable CSF decline in TTR and RBP values.

The stepwise elevation of Hcy plasma levels in healthy aged subjects [109] appears causally related to the gradual downregulation of influences exerted by sex hormones and growth factors on LBM and TTR parameters during the adult lifetime [8]. In contrast, watersoluble B-vitamins are reportedly without effect on the gradual Hcy plasma rise described in healthy elderly persons [110]. It is of interest to remind that TTR plasma concentrations display gender dimorphism during the full sexual maturity period with lower values measured in healthy women [41] that appear to be correlated with their lighter LBM reserves [8] principally explained by a significant reduction in skeletal muscular mass [18]. Theoretically, such LBM handicap should render women more exposed to develop premature dementia, an increased vulnerability nevertheless rarely observed before the timing of menopause [111]. The likely explanation lies in the fact that estrogens manifest potent neuroprotective effects on several brain target sites [112]. Strong support to the estrogenic concept is provided by clinical studies showing that female patients undergoing premenopausal oophorectomy incur higher AD risk [113]. After the age of 65 years, and despite discrepant data between incidence population studies, the prevailing

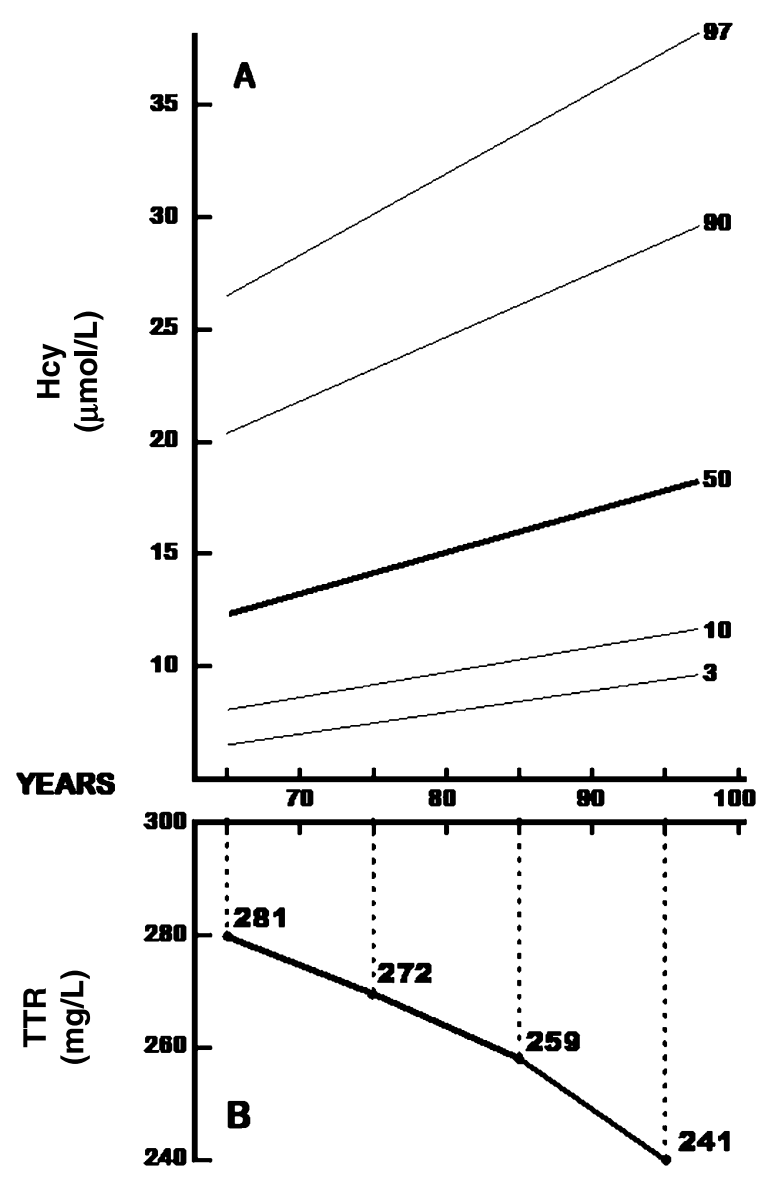

Fig. 3. Total plasma Hcy (A) and mean TTR (B) values in elderly persons aged 65 to 100 years. A) Bates et al. [109] studied freeliving British elderly persons ( 375 men and 373 women totaling 748 subjects) stratified into three groups aged 65-74, 75-84, and 85 years or more. Because gender exerted only minor influence, Hcy concentrations for both sexes were combined, submitted to logarithmic transformation before regression analysis. The study shows the 3rd, 10th, 50th, 90th, and 97th reference centiles calculated for the physiological elevation of Hcy in process of age. B) Bienvenu et al. $[8,41]$ investigated 17,645 healthy US elderly persons $(5,796$ men and 11,849 women) subdivided into four groups aged 61-70, 71-80, 81-90, and 91-100 years and combining both sexes. The study shows the physiological lowering of TTR values with increasing age, the mean value being indicated in bold characters in each of the four categories. 
tendency suggests that women are disproportionally affected by AD [111,114], especially after the age of 80-85 years [115].

Figure 3 outlines the divergent relationships linking the physiological lowering of the LBM-TTR couple with the physiological elevation of Hcy values in healthy elderly persons and the likelihood to develop cerebral disability therefrom. Any causal factor impairing normal LBM replenishment as seen in protein malnutrition $[52,116]$ or depleting LBM stores as documented in acute or chronic inflammatory diseases [48, $55,117]$ further distort both LBM/Hcy relationships while keeping unaltered the mirror image of each other. As a result of LBM shrinking, evidence has accumulated that the increased levels of total Hcy flowing into CSF [118] promote ROS lesions [119] and potentiate senile $A \beta$ plaque neurotoxicity [120], hence operating as a strong, independent risk factor for $\mathrm{AD}$. In addition, LBM downsizing impairs the TS pathway and the production of Cys and GSH, inhibits in turn the enzymatic and nonenzymatic production of $\mathrm{H}_{2} \mathrm{~S}$ in brain tissues [47, 78], preventing the gaseous transmitter from normally antagonizing ROS burden [79, 121] and Hcy-induced harmful effects [80, 81, 122]. Summing up, malnutrition-induced reduction in size of LBM affects AD patients through the mediation of opposite biological mechanisms mutually reinforcing their detrimental effects on brain activities. TTR laboratory testing should be part of any clinical check-up and laboratory exploration [123] helping to identify and to follow-up the undesirable consequences of protein deficiency in AD patients [6,7] in accordance with the statement that "upholding an appropriate LBM status must remain the major outcome measure of protein-related health" [124].

\section{DISCLOSURE STATEMENT}

Authors' disclosures available online (http://www.jalz.com/disclosures/view.php?id=2584).

\section{REFERENCES}

[1] Ingenbleek Y, De Visscher M, De Nayer P (1972) Measurement of prealbumin as index of protein-calorie malnutrition. Lancet 300, 106-109.

[2] Ogunshina SO, Hussain MA (1980) Plasma thyroxine binding prealbumin as index of mild protein- energy malnutrition in Nigerian children. Am J Clin Nutr 33, 794-800.

[3] Dramaix M, Brasseur D, Donnen P, Bahwere P, Porignon D, Tonglet R, Hennart P (1996) Prognostic indices for mortality of hospitalized children in central Africa. Am J Epidemiol 143, 1235-1243.

[4] Devoto G, Gallo F, Marchello C, Racchi O, Garbarini R, Bonassi S, Albalustri G, Haupt E (2006) Prealbumin serum concentrations as a useful tool in the assessment of malnutrition in hospitalized patients. Clin Chem 52, 2281-2285.

[5] Devakonda A, George L, Raoof S, Esan A, Saleh A, Bernstein LH (2008) Transthyretin as a marker to predict outcome in critically ill patients. Clin Biochem 41, 1126-1130.

[6] Han SH, Jung ES, Sohn JH, Hong HJ, Hong HS, Kim JW, Na DL, Kim M, Kim H, Ha HJ, Kim YH, Huh N, Jung MW, Mook-Jung I (2011) Human serum transthyretin levels correlate inversely with Alzheimer's disease. J Alzheimers Dis 25, 77-84.

[7] Velayudhan L, Killick R, Hye A, Kinsey A, Güntert A, Lynham S, Ward M, Leung R, Lourdusamy A, To AW, Powell J, Lovestone S (2012) Plasma transthyretin as a candidate marker for Alzheimer's disease. J Alzheimers Dis $\mathbf{2 8}$, 369-375.

[8] Ingenbleek Y. (2009) Plasma transthyretin reflects the fluctuations of lean body mass in health and disease. In Recent Advances in Transthyretin Evolution, Structure and Biological Functions, Richardson SJ, Cody V, eds. Springer-Verlag, Berlin, pp. 329-357.

[9] Forbes GB (1987) Human Body Composition. Growth, Aging, Nutrition and Activity, Springer-Verlag, Berlin.

[10] Cohn SH, Vartsky D, Yasumura S, Vaswani AN, Ellis KJ (1983) Indexes of body cell mass: Nitrogen versus potassium. Am J Physiol 244, E305-E310.

[11] Forbes GB (1990) Body composition. In Present Knowledge in Nutrition, 6th edition, Brown ML, ed. ILSI Nutrition Foundation, Washington DC, pp. 7-12.

[12] Ingenbleek Y, Young VR (2002) Significance of transthyretin in protein metabolism. Clin Chem Lab Med 40, 1281-1291.

[13] Brožek J, Grande F (1955) Body composition and basal metabolism in man: Correlation analysis versus physiological approach. Hum Biol 27, 22-31.

[14] Barle H, Nyberg B, Essén P, Andersson K, McNurlan MA, Wernerman J, Garlick PJ (1997) The synthesis rates of total liver protein and plasma albumin determined simultaneously in vivo in humans. Hepatology 25, 154-158.

[15] McNurlan MA, Essén P, Heys SD, Buchan V, Garlick PJ, Wernerman J (1991) Measurement of protein synthesis in human skeletal muscle: Further investigation of the flooding technique. Clin Sci (Lond) 81, 557-564.

[16] Nakshabendi IM, McKee R, Downie S, Russell RI, Rennie MJ (1999) Rates of small intestinal mucosal protein synthesis in human jejunum and ileum. Am J Physiol Endocrinol Metab 277, E1028-E1031.

[17] McNurlan MA, Sandgren A, Hunter K, Essén P, Garlick PJ, Wernerman J (1996) Protein synthesis rates of skeletal muscle, lymphocytes, and albumin with stress hormone infusion in healthy man. Metabolism 45, 1388-1394.

[18] Janssen I, Heymsfield SB, Wang ZM, Ross R (2000) Skeletal muscle mass and distribution in 468 men and women aged 18-88 yr. J Appl Physiol 89, 81-88.

[19] Illner K, Brinkmann G, Heller M, Bosy-Westphal A, Müller MJ (2000) Metabolically active components of fat free mass and resting energy expenditure in nonobese adults. Am J Physiol Endocrinol Metab 278, E308-E315.

[20] Johansson AC, Attman PO, Haraldsson B (1997) Creatinine generation rate and lean body mass: A critical analysis in peritoneal dialysis patients. Kidney Int 51, 855-859.

[21] Sreedhara R, Avram MM, Blanco M, Batish R, Avram MM, Mittman N (1996) Prealbumin is the best nutritional predictor of survival in hemodialysis and peritoneal dialysis. Am J Kidney Dis 28, 937-942. 
[22] Dabek JT, Vartsky D, Dykes PW, Hardwicke J, Thomas BG, Fremlin JH, James H (1977) Prompt gamma neutron activation analysis to measure whole body nitrogen absolutely. Its implication to studies of in vivo changes in body composition in health and disease. J Radioanal Chem 37, 325-331.

[23] Schreiber G (2002) The evolution of transthyretin synthesis in the choroid plexus. Clin Chem Lab Med 40, 1200-1210.

[24] Power DM, Elias NP, Richardson SJ, Mendes J, Soares CM, Santos CR (2000) Evolution of the thyroid hormone-binding protein, transthyretin. Gen Comp Endocrinol 119, 241-255.

[25] Stauder AJ, Dickson PW, Aldred AR, Schreiber G, Mendelsohn P, Hudson P (1986) Synthesis of transthyretin (pre-albumin) mRNA in choroid plexus epithelial cells, localized by in situ hybridization in rat brain. $J$ Histochem Cytochem 34, 949-952.

[26] Herbert J, Wilcox JN, Pham KT, Fremeau RT Jr, Zeviani M, Dwork A, Soprano DR, Makover A, Goodman DS, Zimmerman EA (1986) Transthyretin: A choroid plexus-specific transport protein in human brain. Neurology 36, 900-911.

[27] Kabat EA, Moore DH, Landow H (1942) An electrophoretic study of the protein components in cerebrospinal fluid and their relationship to the serum proteins. J Clin Invest $\mathbf{2 1}$, 571-577.

[28] Schultze HE, Schönenberger M, Schwick G (1956) Uber ein präalbumin des menschlichen serums. Biochem $Z \mathbf{3 2 8}$, 267-284.

[29] Kanda Y, Goodman DS, Canfield RE, Morgan FJ (1974) The amino acid sequence of human plasma prealbumin. J Biol Chem 249, 6796-6805.

[30] Ingbar SH (1958) Pre-albumin: A thyroxine-binding protein of human plasma. Endocrinology 63, 256-259.

[31] Kanai M, Raz A, Goodman DS (1968) Retinol-binding protein: The transport protein for vitamin A in human plasma. J Clin Invest 47, 2025-2044.

[32] Monaco HL (2009) The transthyretin-retinol binding protein complex. In Recent Advances in Transthyretin Evolution, Structure and Biological Functions, Richardson SJ, Cody V, eds. Springer-Verlag, Berlin, pp. 123-142.

[33] Goodman DS, Peters T, Robbins J, Schwick G (1981) Prealbumin becomes transthyretin. Nomenclature CommitteeIUB and JCBN Newsletter. J Biol Chem 256, 12-14.

[34] Socolow EL, Woeber KA, Purdy RH, Holloway MT, Ingbar SH (1965) Preparation of I-131-labeled human serum prealbumin and its metabolism in normal and sick patients. J Clin Invest 44, 1600-1609.

[35] Peterson PA, Nilsson S, Ostberg L, Rask L, Vahlquist A (1974) Aspects of the metabolism of retinol-binding protein and retinol. Vitam Horm 32, 181-214.

[36] Ingenbleek Y, Van den Schrieck HG, De Nayer P, De Visscher M (1975) The role of retinol- binding protein in protein-calorie malnutrition. Metabolism 24, 633-641.

[37] Makover A, Moriwaki H, Ramakrishnan R, Saraiva MJ, Blaner WS, Goodman DS (1988) Plasma transthyretin. Tissue sites of degradation and turnover in the rat. J Biol Chem 263, 8598-8603.

[38] Vahlquist A, Rask L, Peterson PA, Berg T (1975) The concentrations of retinol-binding protein, prealbumin, and transferrin in the sera of newly delivered mothers and children of various ages. Scand J Clin Lab Invest 35, 569-575.

[39] Veldhuis JD, Roemmich JN, Richmond EJ, Rogol AD, Lovejoy JC, Sheffield-Moore M, Mauras N, Bowers CY (2005) Endocrine control of body composition in infancy, childhood, and puberty. Endocr Rev 26, 114-146.
[40] Ingenbleek Y, De Visscher M (1979) Hormonal and nutritional status: Critical conditions for endemic goiter epidemiology? Metabolism 28, 9-19.

[41] Bienvenu J, Jeppson JO, Ingenbleek Y. (1996) Transthyretin \& retinol-binding protein. In Serum Proteins in Clinical Medicine, Ritchie RF, Navolotskaia O, eds. Foundation for Blood Research, Scarborough, pp. 9.011-9.018.

[42] Geisler JP, Linnemeirer GC, Thomas AJ, Manahan KJ (2007) Nutritional assessment using prealbumin as an objective criterion to determine whom should not undergo primary radical cytoreductive surgery for ovarian cancer. Gynecol Oncol 106, 128-131.

[43] Ho SY, Guo HR, Chen HH, Peng CJ (2003) Nutritional predictors of survival in terminally ill cancer patients. J Formos Med Assoc 102, 544-550.

[44] Bernstein LH, Ingenbleek Y (2002) Transthyretin: Its response to malnutrition and stress injury. Clinical usefulness and economic implications. Clin Chem Lab Med 40, 1344-1348.

[45] Straus DS, Marten NW, Hayden JM, Burke EJ (1994) Protein restriction specifically decreases the abundance of serum albumin and transthyretin nuclear transcripts in rat liver. J Nutr 124, 1041-1051.

[46] Ingenbleek Y, Young V (1994) Transthyretin (prealbumin) in health and disease: Nutritional implications. Annu Rev Nutr 14, 495-533.

[47] Ingenbleek Y, Kimura H (2013) Nutritional essentiality of sulfur in health and disease. Nutr Rev 71, 413-432.

[48] Arnold J, Campbell IT, Samuels TA, Devlin JC, Green CJ, Hipkin LJ, McDonald IA, Scrimgeour CM, Smith K, Rennie MJ (1993) Increased whole body protein breakdown predominates over increased whole body protein synthesis in multiple organ failure. Clin Sci (Lond) 84, 655-661.

[49] Okawa H, Morita T, Sugiyama K (2006) Increased plasma homocysteine concentration in rats from a low casein diet. Biosci Biotechnol Biochem 70, 3050-3053.

[50] Elshorbagy AK, Valdivia-Garcia M, Refsum H, Smith AD, Mattocks DA, Perrone CE (2010) Sulfur amino acids in methionine-restricted rats: Hyperhomocysteinemia. Nutrition 26, 1201-1204.

[51] Ingenbleek Y, Barclay D, Dirren H (1986) Nutritional significance of alterations in serum amino acid patterns in goitrous patients. Am J Clin Nutr 43, 310-319.

[52] Ingenbleek Y, McCully KS (2012) Vegetarianism produces subclinical malnutrition, hyperhomocysteinemia and atherogenesis. Nutrition 28, 148-153.

[53] Murakami T, Ohnishi S, Nishiguchi S, Maeda S, Araki S, Shimada K (1988) Acute-phase response of mRNAs for serum amyloid $\mathrm{P}$ component, C-reactive protein and prealbumin (transthyretin) in mouse liver. Biochem Biophys Res Commun 155, 554-560.

[54] Banks RE, Forbes MA, Storr M, Higginson J, Thompson D, Raynes J, Illingworth JM, Perren TJ, Selby PJ, Whicher JT (1995) The acute phase response in patients receiving subcutaneous IL-6. Clin Exp Immunol 102, 217-223.

[55] Schindler K, Zauner C, Buchmayer H, Födinger M, Wölfl G, Bieglmayer C, Heinz G, Wilfing A, Hörl WH, Sunder-Plassmann G (2000) High prevalence of hyperhomocysteinemia in critically ill patients. Crit Care Med 28, 991-995.

[56] Fuller FM, McWilliam R, Wang TC, Giles LR (1989) The optimum dietary amino acid pattern for growing pigs. 2 . Requirements for maintenance and for tissue protein accretion. Br J Nutr 62, 255-267. 
[57] Finkelstein JD. (1998) The metabolism of homocysteine: Pathways and regulation. Eur J Pediatr 157 (Suppl. 2), S 40-48.

[58] Tang B, Mustafa A, Gupta S, Melnyk S, James SJ, Kruger WD (2010) Methionine-deficient diet induces posttranscriptional downregulation of cystathionine $\beta$-synthase. Nutrition 26, 1170-1175.

[59] Richie JP Jr, Komninou D, Leutzinger Y, Kleinman W, Orentreich N, Malloy V, Zimmerman JA (2004) Tissue glutathione and cysteine levels in methionine-restricted rats. Nutrition 20, 800-805.

[60] Ingenbleek Y (2006) The nutritional relationship linking sulfur to nitrogen in living organisms. J Nutr 136(Suppl. 6), S1641-S1651.

[61] Hung CJ, Huang PC, Lu SC, Li YH, Huang HB, Lin BF, Chang SJ, Chou HF (2002) Plasma homocysteine levels in Taiwanese vegetarians are higher than those of omnivores. J Nutr 132, 152-158.

[62] Koebnick C, Garcia AL, Dagnelie PC, Strassner C, Lindemans J, Katz N, Leitzmann C, Hoffmann I (2005) Long-term consumption of a raw food diet associated with favorable serum LDL cholesterol and triglycerides but also with elevated plasma homocysteine and low serum HDL cholesterol in humans. J Nutr 135, 2372-2378.

[63] Young VR, Pellet PL (1990) Current concepts concerning amino acids in adults and their implications for international planning. Food Nutr Bull 12, 289-300.

[64] Querfurth HW, LaFerla FM (2010) Alzheimer's disease. $N$ Engl J Med 362, 329-344

[65] Candelorio-Jalil E, Yang Y, Rosenberg GA (2009) Diverse roles of matrix metalloproteinases and tissue inhibitors of metalloproteinases in neuroinflammation and cerebral ischemia. Neuroscience 158, 983-994.

[66] Benson MD (1989) Familial amyloidotic polyneuropathy. Trends Neurosci 12, 88-92.

[67] Andrade C (1952) A peculiar form of peripheral neuropathy; familial atypical generalized amyloidosis with special involvement of the peripheral nerves. Brain 75, 408-427.

[68] Ando Y, Ueda M (2012) Diagnosis and therapeutic approaches to transthyretin amyloidosis. Curr Med Chem 19, 2312-2323

[69] Saraiva MJ, Costa PP, Goodman DS (1983) Studies on plasma transthyretin (prealbumin) in familial amyloidotic polyneuropathy, Portuguese type. J Lab Clin Med 102, 590603.

[70] Linke RP (1982) Immunohistochemical identification and cross reactions of amyloid fibril proteins in senile heart and amyloid in familial polyneuropathy. Lack of reactivity with cerebral amyloid in Alzheimer's disease. Clin Neuropathol 1, 172-182.

[71] Rozemuller AJ, Roos RA, Bots GT, Kamphorst W, Eikelenboom P, Van Nostrand WE (1993) Distribution of beta/A4 protein and amyloid precursor protein in hereditary cerebral hemorrhage with amyloidosis-Dutch type and Alzheimer's disease. Am J Pathol 142, 1449-1457.

[72] Verslegers M, Lemmens K, Van Hove I, Moons L (2013) Matrix metalloproteinase- 2 and -9 as promising benefactors in development, plasticity and repair of the nervous system. Prog Neurobiol 105, 60-78.

[73] Mroczko B, Groblewska M, Barcikowska M (2013) The role of matrix metalloproteinases and tissue inhibitors of metalloproteinases in the pathophysiology of neurodegeneration: A literature study. J Alzheimers Dis 37, 273-283.

[74] Backstrom JR, Lim GP, Cullen MJ, Tökés ZA (1996) Matrix metalloproteinase-9 (MMP-9) is synthesized in neurons of the human hippocampus and is capable of degrading amyloid- $\beta$ peptide (1-40). J Neurosci 16, 7910-7919.

[75] Lin MT, Beal MF (2006) Mitochondrial dysfunction and oxidative stress in neurodegenerative diseases. Nature $\mathbf{4 4 3}$, 787-795.

[76] Xie Z, Culley DJ, Dong Y, Zhang G, Zhang B, Moir RD, Frosch MP, Crosby G, Tanzi RE (2008) The common inhalation anesthetic isoflurane induces caspase activation and increases A $\beta$ protein level in vivo. Ann Neurol 64, 618-627.

[77] Yan P, Hu X, Song H, Yin K, Bateman RS, Cirrito JR, Xiao Q, Hsu FF, Turk JW, Xu J, Hsu CY, Holtzman DM, Lee JM (2006) Matrix metalloproteinases-9 degrades amyloid$\beta$ fibrils in vitro and compact plaques in situ. J Biol Chem 281, 24566-24574.

[78] Eto K, Asada T, Arima K, Makifuchi T, Kimura H (2002) Brain hydrogen sulfide is severely decreased in Alzheimer's disease. Biochem Biophys Res Commun 293, 1485-1488.

[79] Kimura Y, Kimura H (2004) Hydrogen sulfide protects neurons from oxidative stress. FASEB J 18, 1165-1167.

[80] Tyagi N, Givvimani S, Qipshidze N, Kundu S, Kapoor S, Vacek JC, Tyagi SC (2010) Hydrogen sulfide mitigates matrix metalloproteinase- 9 activity and neurovascular permeability in hyperhomocysteinemic mice. Neurochem Int 56, 301-307.

[81] Kamat PK, Kalani A, Givvimani S, Sathnur PB, Tyagi SC, Tyagi N (2013) Hydrogen sulfide attenuates neurodegeneration and neurovascular dysfunction induced by intracerebral-administered homocysteine in mice. Neuroscience 252, 302-319.

[82] Toohey JI (2011) Sulfur signaling: Is the agent sulfide or sulfane? Anal Biochem 413, 1-7.

[83] Kim JJ, Ha AW, Kim HS, Kim WK (2011) Inorganic sulfur reduces the mobility and invasion of MDA-MB-231 human breast cancer cells. Nutr Res Pract 5, 375-380.

[84] Lee J, Lee HJ, Park JD, Lee SK, Lee SI, Lim HD, Lee YM, Yun YG, Jeon BH, Ree IS, Jun CD, Lee SK, Kim EC (2008) Anti-cancer activity of highly purified sulfur in immortalized and malignant human oral keratinocytes. Toxicol In Vitro 22, 87-95.

[85] Brouillette J, Quirion R (2008) Transthyretin: A key gene involved in the maintenance of memory capacities during aging. Neurobiol Aging 29, 1721-1732.

[86] Sousa JC, Marques F, Dias-Ferreira E, Cerqueira JJ, Sousa N, Palha JA (2007) Transthyretin influences spatial reference memory. Neurol Learn Mem 88, 381-385.

[87] Sousa JC, Grandela C, Fernández-Ruiz J, de Miguel R, de Sousa L, Magalhães AI, Saraiva MJ, Sousa N, Palha JA (2004) Transthyretin is involved in depression-like behaviour and exploratory activity. J Neurochem $\mathbf{8 8}, 1052$ 1058.

[88] Fleming CE, Saraiva MJ, Sousa MM (2007) Transthyretin enhances nerve regeneration. J Neurochem 103, 831-839.

[89] Santos SD, Lambertsen KL, Clausen BH, Akinc A, Alvarez R, Finsen B, Saraiva MJ (2010) CSF transthyretin neuroprotection in a mouse model of brain ischemia. $J$ Neurochem 115, 1434-1444.

[90] Chen RL, Athauda SB, Kassem NA, Zhang Y, Segal MB, Preston JE (2005) Decrease of transthyretin synthesis at the blood-cerebrospinal fluid barrier of old sheep. J Gerontol A Biol Sci Med Sci 60, 852-858.

[91] Dickson PW, Aldred AR, Marley PD, Bannister D, Schreiber G (1986) Rat choroid plexus specializes in the synthesis and secretion of transthyretin (prealbumin). Regulation of transthyretin synthesis in choroid plexus is independent from that of liver. J Biol Chem 261, 3475-3478. 
[92] Schwarzman AL, Gregori L, Vitek MP, Lyubski S, Strittmatter WJ, Enghilde JJ, Bhasin R, Silverman J, Weisgraber KH, Coyle PK (1994) Transthyretin sequesters amyloid $\beta$ protein and prevents amyloid formation. Proc Natl Acad Sci U S A 91, 8368-8372.

[93] Fex GA, Larsson K, Nilsson-Ehle I (1996) Serum concentrations of all-trans- and 13-cis retinoic acid and retinol are closely correlated. J Nutr Biochem 7, 162-165.

[94] Goodman AB, Pardee AB (2003) Evidence for defective retinoid transport and function in late onset Alzheimer's disease. Proc Natl Acad Sci U S A 100, 2901-2905.

[95] Etchamendy N, Enderlin V, Marighetto A, Vouimba RM, Pallet V, Jaffard R, Higueret P (2001) Alleviation of a selective age-related relational memory deficit in mice by pharmacologically induced normalization of brain retinoid signaling. J Neurosci 21, 6423-6429.

[96] Corcoran JP, So PL, Maden M (2004) Disruption of the retinoid signaling pathway causes a deposition of amyloid beta in the adult rat brain. Eur J Neurosci 20, 896-902.

[97] Husson M, Enderlin V, Delacourte A, Ghenimi N, Alfos S, Pallet V, Higueret P (2006) Retinoic acid normalizes nuclear receptor mediated hypo-expression of proteins involved in beta-amyloid deposits in the cerebral cortex of vitamin A deprived rats. Neurobiol Dis 23, 1-10.

[98] Ono K, Yoshiike Y, Takashima A, Hasegawa K, Naiki H, Yamada M (2004) Vitamin A exhibits potent antiamyloidogenic and fibril-destabilizing effects in vitro. Exp Neurol 189, 380-392.

[99] Acin-Perez R, Hoyos B, Zhao F, Vinogradov V, Fishman DA, Harris RA, Leitges M, Wongsiriroj N, Blaner WS, Manfredi G, Hammerling U (2010) Control of oxidative phosphorylation by vitamin A illuminates a fundamental role in mitochondrial energy homeostasis. FASEB $J \mathbf{2 4}$, 627-636.

[100] Sandman PO, Adolfsson R, Nygren C, Hallmans G, Winblad B (1987) Nutritional status and dietary intake in institutionalized patients with Alzheimer's disease and multiinfarct dementia. J Am Geriatr Soc 35, 31-38.

[101] Riisøen H (1988) Reduced prealbumin (transthyretin) in CSF of severely demented patients with Alzheimer's disease. Acta Neurol Scand 78, 455-459.

[102] Gloeckner SF, Meyne F, Wagner F, Heinemann U, Krasnianski A, Meissner B, Zerr I (2008) Quantitative analysis of transthyretin, tau and amyloid- $\beta$ in patients with dementia. J Alzheimers Dis 14, 17-25.

[103] Jung SM, Lee K, Lee JW, Namkoong H, Kim HK, Kim S, Na HR, Ha SA, Kim JR, Ko J, Kim JW (2008) Both retinolbinding protein and haptoglobin precursor allele 1 in CSF: Candidate biomarkers for the progression of normal to mild cognitive impairment to Alzheimer's disease. Neurosci Lett 436, 153-157.

[104] Goodman AB (2006) Retinoid receptors, transporters, and metabolizers as therapeutic targets in late onset Alzheimer disease. J Cell Physiol 209, 598-603.

[105] Lerner AJ, Gustaw-Rothenberg K, Smyth S, Casadesus G (2012) Retinoids for treatment of Alzheimer's disease. Biofactors 38, 84-89.

[106] Sullivan GM, Hatterer JA, Herbert J, Chen X, Roose SP, Attia E, Mann JJ, Marangell LB, Goetz RR, Gorman JM (1999) Low levels of transthyretin in the CSF of depressed patients. Am J Psychiatry 156, 710-715.

[107] Wan C, Yang Y, Li H, La Y, Zhu H, Jiang L, Chen Y, Feng G, He L (2006) Dysregulation of retinoid transporters expression in body fluids of schizophrenia patients. J Proteome Res 5, 3213-3216.
[108] Yang YR, Liu SL, Qin ZY, Liu FJ, Qin YJ, Bai SM, Chen ZY (2008) Comparative proteomics analysis of cerebrospinal fluid of patients with Guillain-Barré syndrome. Cell Mol Neurobiol 28, 737-744.

[109] Bates CJ, Mansoor MA, van der Pols J, Prentice A, Cole TJ, Finch S (1997) Plasma total homocysteine in a representative sample of 927 British men and women aged 65 and over. Eur J Clin Nutr 51, 691-697.

[110] Strassburg A, Krems C, Lührmann PM, Hartmann B, Neuhäuser-Berthold M (2004) Effect of age on plasma homocysteine concentrations in young and elderly subjects considering serum vitamin concentrations and different lifestyle factors. Int J Vitam Nutr Res 74, 129-136.

[111] Zhou DF, Wu CS, Qi H, Fan JH, Sun XD, Como P, Qiao YL, Zhang L, Kieburtz K (2006) Prevalence of dementia in rural China: Impact of age, gender and education. Acta Neurol Scand 114, 273-280.

[112] Henderson VW (2006) Estrogen-containing hormone therapy and Alzheimer's disease risk: Understanding discrepant inferences from observational and experimental research. Neuroscience 138, 1031-1039.

[113] Rocca WA, Bower JH, Maraganore DM, Ahlskog JE, Grossardt BR, de Andrade M, Melton LJ 3rd (2007) Increased risk of cognitive impairment or dementia in women who underwent oophorectomy before menopause. Neurology 69, 1074-1083.

[114] Gao S, Hendrie HC, Hall KS, Hui S (1998) The relationships between age, sex, and the incidence of dementia and Alzheimer disease: A meta-analysis. Arch Gen Psychiatry $\mathbf{5 5}, 809-815$.

[115] Mielke MM, Vemuri P, Rocca WA (2014) Clinical epidemiology of Alzheimer's disease: Assessing sex and gender differences. Clin Epidemiol 6, 37-48.

[116] Ingenbleek Y, Hardillier E, Jung L (2002) Subclinical protein malnutrition is a determinant of hyperhomocysteinemia. Nutrition 18, 40-46.

[117] Gori AM, Corsi AM, Fedi S, Gazzini A, Sofi F, Bartali B, Bandinelli S, Gensini GF, Abbate R, Ferrucci L (2005) A proinflammatory state is associated with hyperhomocysteinemia in the elderly. Am J Clin Nutr 82, 335-341.

[118] Isobe C, Murata T, Sato C, Terayama Y (2005) Increase of total homocysteine concentration in cerebrospinal fluid of patients with Alzheimer's disease and Parkinson's disease. Life Sci 77, 1836-1843.

[119] Perna AF, Ingrosso D, De Santo NG (2003) Homocysteine and oxidative stress. Amino Acids 25, 409-417.

[120] Ho PI, Collins SC, Dhitavat S, Ortiz D, Ashline D, Rogers E, Shea TB (2001) Homocysteine potentiates $\beta$-amyloid neurotoxicity: Role of oxidative stress. J Neurochem 78, 249-253.

[121] Kimura Y, Dargush R, Schubert D, Kimura H (2006) Hydrogen sulfide protects HT22 neuronal cells from oxidative stress. Antioxid Redox Signal 8, 661-670.

[122] Tang XQ, Shen XT, Huang YE, Ren YK, Chen RQ, Hu B, He JQ, Yin WL, Xu JH, Jiang ZS (2010) Hydrogen sulfide antagonizes homocysteine-induced neurotoxicity in PC12 cells. Neurosci Res 68, 241-249.

[123] David G, Bernstein LH, Coifman RR (2013) The automated malnutrition assessment. Nutrition 29, 113-121.

[124] Millward DJ, Jackson AA (2003) Protein/energy ratio of current diets in developed and developing countries with a safe protein/energy ratio: Implications for recommended protein and amino acid intakes. Public Health Nutr 7, 387-405. 